\title{
Benefits, Open questions and Challenges of the use of Ultrasound in the COVID-19 pandemic era. The views of a panel of worldwide international experts
}

\section{Vorteile, offene Fragen und Herausforderungen des Einsatzes von Ultraschall in der Ära der COVID-19-Pandemie. Die Ansichten einer Gruppe von internationalen Experten aus aller Welt}

Authors

Fabio Piscaglia ${ }^{*}$, Federico Stefanini ${ }^{1}$, Vito Cantisani ${ }^{2}$, Paul S. Sidhu ${ }^{3}$, Richard Barr ${ }^{4}$, Annalisa Berzigotti ${ }^{5}$, Maria Cristina Chammas ${ }^{6}$, Jean-Michel Correas ${ }^{7}$, Christoph Frank Dietrich ${ }^{8}$, Steven Feinstein ${ }^{9}$, Pintong Huang ${ }^{10}$, Christian Jenssen ${ }^{11}$, Yuko Kono ${ }^{12}$, Masatoshi Kudo ${ }^{13}$, Ping Liang ${ }^{14}$, Andrej Lyshchik ${ }^{15}$, Christian Nolsøe ${ }^{16}$, Xyaoyan Xie ${ }^{17}$, Francesco Tovoli $^{1 *}$

Affiliations

1 COVID-19 Unit \& Unit of Internal Medicine, Azienda Ospedaliero Universitaria S.Orsola Malpighi, Bologna, Italy

2 Radiological, Anatomo-pathological and Oncologic Sciences Department, Policlinico Umberto I, University La Sapienza, Rome, Italy

3 Department of Radiology, King's College London. King's College Hospital, London, UK

4 Radiology, Northeastern Ohio Medical University, USA

5 Hepatology, University Clinic for visceral surgery and medicine, Inselspital, University of Bern, Switzerland

6 Ultrasound Division of Hospital das Clínicas, School of Medicine, University of São Paulo, São Paulo, Brazil

7 Department of Adult Radiology, Paris University \& Necker University Hospital, Paris, France

8 Kliniken Hirslanden Beau Site, Salem und Permanence, Bern, Switerzeland

9 Rush Universty Medical Center, Chicago, USA

10 Department of Ultrasound in Medicine,the Second Affiliated Hospital of Zhejiang University School of Medicine, China

11 Department of Internal Medicine, Krankenhaus MärkischOderland, Strausberg, and Brandenburg Institute for Clinical Ultrasound (BICUS), Medical University Brandenburg, Neuruppin, Germany

12 Department of Medicine, Radiology, University of California, San Diego, USA

13 Department of Gastroenterology and Hepatology, Kindai University Faculty of Medicine, Japan

14 Interventional Ultrasound Department, Chinese PLA General Hospital, Beijing, China
15 Radiology Unity, Thomas Jefferson University Hospital, Philadelphia, USA

16 Centre for Surgical Ultrasound, Dep of Surgery, Zealand University Hospital, Køge, Copenhagen Denmark

17 Institute of Diagnostic and Interventional Ultrasound The First Affiliated Hospital of Sun Yat-Sen University,

Guangzhou, China

Bibliography

DOI https://doi.org/10.1055/a-1149-9872

Published online: April 15, 2020

Ultraschall in Med 2020; 41: 228-236

(c) Georg Thieme Verlag KG, Stuttgart · New York

ISSN 0172-4614

Correspondence

Fabio Piscaglia

Unit of Internal Medicine, Azienda Ospedaliero Universitaria S.

Orsola Malpighi di Bologna, via Albertoni 15, 40138, Bologna, Italy

Tel.: ++ 39/51/2142568

Fax: ++ 39/51/2142725

fabio.piscaglia@unibo.it

Francesco Tovoli

Unit of Internal Medicine, Azienda Ospedaliero Universitaria S. Orsola Malpighi di Bologna, via Albertoni 15, 40138, Bologna, Italy

Tel.: ++ 39/51/2142568

Fax: ++ 39/51/2142725

francesco.tovoli2@unibo.it

Co-Shared Corresponding authors. 


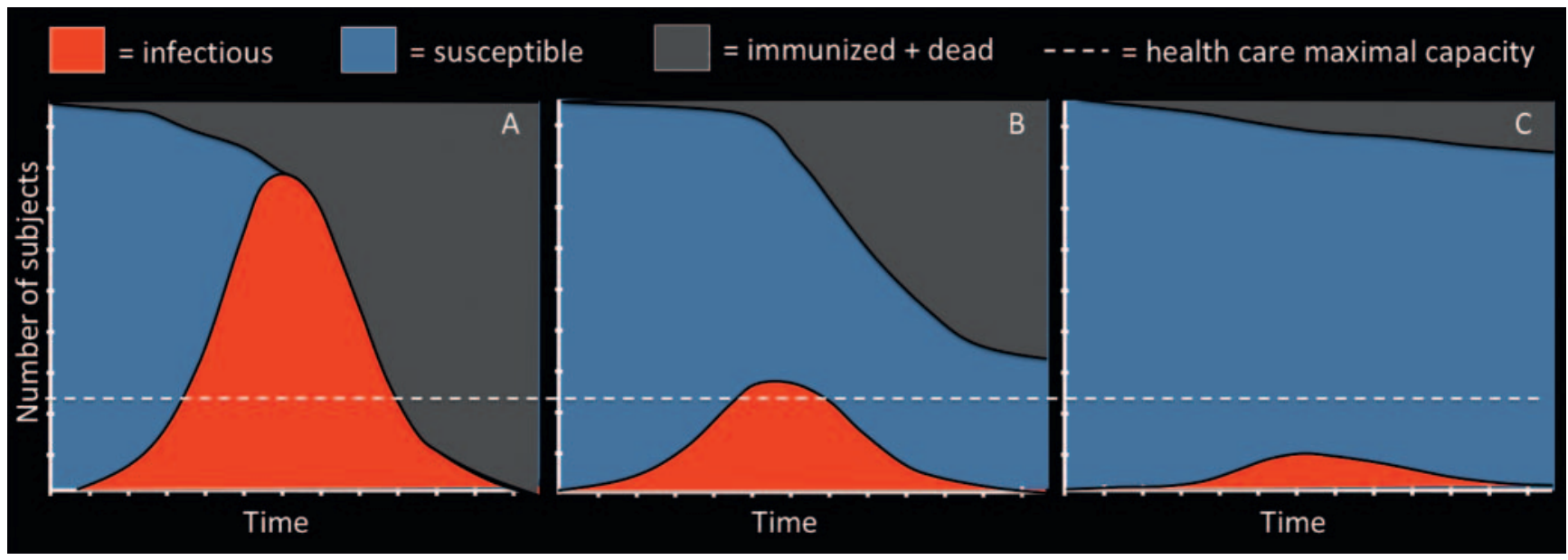

- Fig. 1 Examples of spread of infectious disease under different counteracting measures and burden on the health care system. Panel $A=$ no measure is taken. The agent spreads very fast, making susceptible subjects to disappear and be replaced by dead or immune subjects. During the peak of infected subjects the demand of assistance largely passes the capacity of the health care system to react (dashed white line) and potentially leading to a collapse of healthcare. Panel B = counteracting measures are taken, but not rapidly and intensely enough to avoid the peak of infected subjects passing the capacity of the healthcare system to react. Management of patients out of the best standard of care is necessarily adopted. Panel C: counteracting measures are taken strict and timely enough to avoid the peak of infected subjects to pass the capacity of reaction of the healthcare system, which is able to maintain the best standard of care for everyone.

- Abb. 1 Beispiele für die Ausbreitung von Infektionskrankheiten unter verschiedenen Gegenmaßnahmen und Belastungen für das Gesundheitssystems. Bild A = es wird keine Maßnahme ergriffen. Der Erreger breitet sich sehr schnell aus, so dass empfängliche Individuen verschwinden und durch Tote oder Immune ersetzt werden. Wird die Spitze der Infizierten erreicht, so übersteigt die Nachfrage nach Hilfeleistung bei weitem die Kapazität des Gesundheitssystems (gestrichelte weiße Linie) und führt möglicherweise zu einem Zusammenbruch der Gesundheitsversorgung. Bild B = Gegenmaßnahmen werden ergriffen, jedoch nicht schnell und intensiv genug, um zu verhindern, dass die Spitze der Infizierten die Kapazität des Gesundheitssystems überschreitet. Das Patientenmanagement entspricht nicht den besten Versorgungsstandards und wird notwendigerweise angepasst. Bild C = Gegenmaßnahmen sind strikt und rechtzeitig genug, so dass vermieden wird, dass die Spitze der Infizierten die Kapazität des Gesundheitssystems überschreitet, das noch in der Lage ist, den besten Versorgungsstandard für alle aufrechtzuerhalten.

In the very last days of the year 2019a new virus of the coronavirus family, named Sars-Cov-2 [1] was identified as responsible for the outbreak of cases of human pneumonia in Wuhan, China, a condition named Corona Virus Disease of 2019 (COVID-19). This virus displayed a rapid worldwide spread, with rates significantly higher and with much more severe clinical manifestations than those of seasonal influenza virus. From the initial source in China the virus has progressively spread also to Europe, starting to heavily impact Northern Italy, and later to other European countries and the United States, which by the end of March 2020 has become the country with the largest number of documented cases. Since the virus is new and highly infectious, all humans are potentially susceptible. Moreover, the outbreak took place unexpectedly and in a densely populated Chinese city causing a rapid exponential growth in the number of cases. This led to a huge influx of patients to medical facilities demanding investigation and support for persisting high fever and respiratory compromise. Depending on the local population reaction and the rapidity of local authorities response in combating an infectious diffusive public health threat, different modalities of this epidemic can take place (https://www.youtube.com/watch?v=gxAaO2rsdls) (• Fig. 1). Unfortunately, not only in China, but also in Northern Italy, Spain, France and America, just to name some most hit countries, authority reaction and population restrictions were not sufficiently timely to avoid the exponential growth, producing a burst of cases. This has inevitably resulted in overwhelming the capacity of the healthcare systems, in particular hospital provision, and the ability to properly allocate patients to the appropriate clinical units. This has led, particularly in North Italy and Spain, to the risk of collapse of normally comprehensive and excellent health care systems. The sheer volume of sick patients has overrun the capability of the hospitals to provide the expected healthcare, creating a sort of war scenario.

With no specific disease treatment existing, there are several requirements to try to limit the spread of the infection. There must be early identification of infectious cases, with rapid laboratory testing, ideally with an accurate rapid clinical diagnosis to isolate the positive subjects, preventing further spread of the infection. There should be appropriate triage of positive patients into those who can remain safely at home and those that require hospital admission. It would also be important to predict early any deterioration in order to timely upscaling of the intensity of care (whenever possible) and furthermore, there is need for optimal patient management during respiratory failure and in the intensive care unit stay. The transmission of this easily spreading infection during patient care has also to be avoided.

Since COVID-19 is primarily a respiratory disease [2] the expectation would be that lung imaging would be essential for the diagnosis [3].

Computed tomography $(\mathrm{CT})$ imaging has been reported to be a highly sensitive technique in identifying findings suggestive of COVID-19 pulmonary involvement, which includes bilateral "sub- 
pleural and lower lobe located ground glass" abnormality [4]. Nonetheless, any opacity at CT has low specificity, as these appearances are caused by other viral infections [5]. These good sensitivity and positive predictive values are therefore valid only in the setting of an epidemic COVID-19, when there is a very high "a priori" probability of COVID-19 in the presence of respiratory symptoms. However, even under these conditions the capacity of CT to rule out COVID-19 in the presence of negative pulmonary findings is far from sufficient $[6,7]$.

Against this background, a panel of internation experts has taken the opportunity to evaluate the position of ultrasound (US) in the management of COVID-19, in order to summarize for our journal readers, an outlook of the benefits, but also open questions and challenges of the use of US in the setting of COVID-19 epidemic [8].

Typically, the COVID-19 pulmonary involvement initially affects the declivous areas, corresponding to the superficial areas of the lungs, usually in the posterior basal regions ( $\bullet$ Fig. 2) [4], probably because sick patients tend to sit or lie in bed for most of the time. Fortunately, these areas are explorable with chest US and these areas of abnormality were shown to be possibly detected also early in the course of the disease, as shown by Su et al in this issue of the journal [8]. The pulmonary involvement may then become extensive with the progression not only of the local severity of the disease, but spreading to involve the entire lung fields bilaterally. At the most severe stage, US is nearly invariably able to detect the pulmonary involvement, but the sensitivity of US in the early phase has not yet been definitively elucidated ( $\bullet$ Fig. 2 ).

Typical patterns of the COVID-19 pulmonary involvement are the appearance of multiple B-lines, with heterogeneous involvement of the lungs (mixing $A$ and $B$ patterns nearby, in a different manner from cardiac pulmonary edema, which shows homogeneous increase in B lines), appearance of thickened and irregular pleural contour line, onset of small superficial consolidations and in more severe cases large areas of consolidation with air bronchograms and also minimal or rarely larger pleural space fluid effusions ( $\bullet$ Fig. 3). However, since the role of CT in COVID-19 is still questioned [6], that of US is not unexpectedly even more debated and uncertain.

We would like therefore to suggest a list of potential benefits of US and raise some unanswered clinical questions in this setting:

1) Ultrasound can detect signs of pulmonary involvement [8]. Findings of pulmonary interstitial syndrome ( \pm with consolidations) associated with fever, absolute lymphopenia and variable increase in LDH, ferritin, C-reactive protein and Interleukin-6 [9] are extremely suggestive of COVID-19 in an epidemic setting such as the current situation. Whether or not additional testing, such as throat/nasal swab for RNA testing [10] and/or chest plain $\mathrm{X}$-ray and/or CT imaging remain absolutely and immediately mandatory or alternatively patients can be directly allocated to COVID-19 wards has to remain a decision based on the local and continuously changing circumstances. Crowding of patient at first aid /emergency facilities, time to obtain results of swab RNA testing [10] and chest CT imaging, often taking some hours, particularly when demand is high, have to be taken into consideration.

To correctly establish the appropriate use of US in the diagnostic triage of COVID-19, there is a lack of relevant scientific infor-

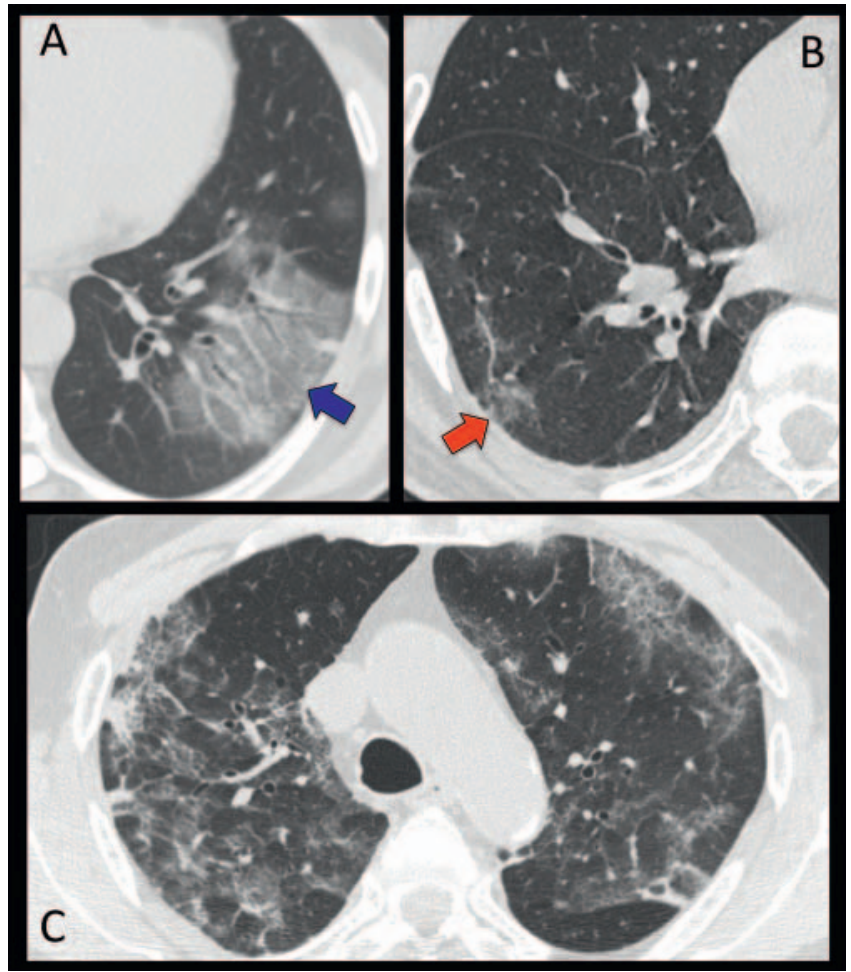

- Fig. 2 Examples of CT appearance of the pulmonary involvement by COVID-19. Panel $A=$ moderate left lung posterodorsal ground glass opacity. Panel B = Mild right lung postero basal subpleural infiltrate. Panel $C$ = extensive bilateral diffuse lung alterations with ground glass appearance, perilobular thickening and small consolidations.

- Abb.2 Beispiele für das CT-Erscheinungsbild der Lungenbeteiligung durch COVID-19. Bild $A=$ moderate posterodorsale Milchglastrübung der linken Lunge. Bild $B=$ Geringes postero-basales subpleurales Infiltrat der rechten Lunge. Bild C = ausgedehnte bilaterale diffuse Lungenveränderungen mit Mllchglaserscheinung, perilobulärer Verdickung und kleinen Konsolidierungen.

mation. Important aspects that are needed include the sensitivity of the US technique for different degrees of pulmonary involvement (Su et al report on a limited number of cases) [8], the positive predictive value either in a setting of COVID-19 endemic disease or under normal conditions, the negative predictive value for mild, moderate and severe involvement. Briefly, despite some benefits of US, its role in clinical decision-making when imaging the individual suspected case is yet to be established.

2) Whether US can be utilized and is cost/effective in detecting the progression (or regression) of the severity of lung involvement over the days, with either in- or out-patients (in other words the capacity to distinguish mild, moderate and severe involvement) is still to be adequately investigated and clarified. A positive answer to this question would bring US into possible use in patient monitoring, potentially integrating with the chest X-ray or CT.

3) There is a potential benefit from the use of US in intensive care units to assess the effect of clinical maneuvers, such as bronchoscopy, aiming at restoring bronchial patency, following an US detection of poorly ventilated large consolidations. Ultrasound can additionally detect pneumothorax, which occurs either 


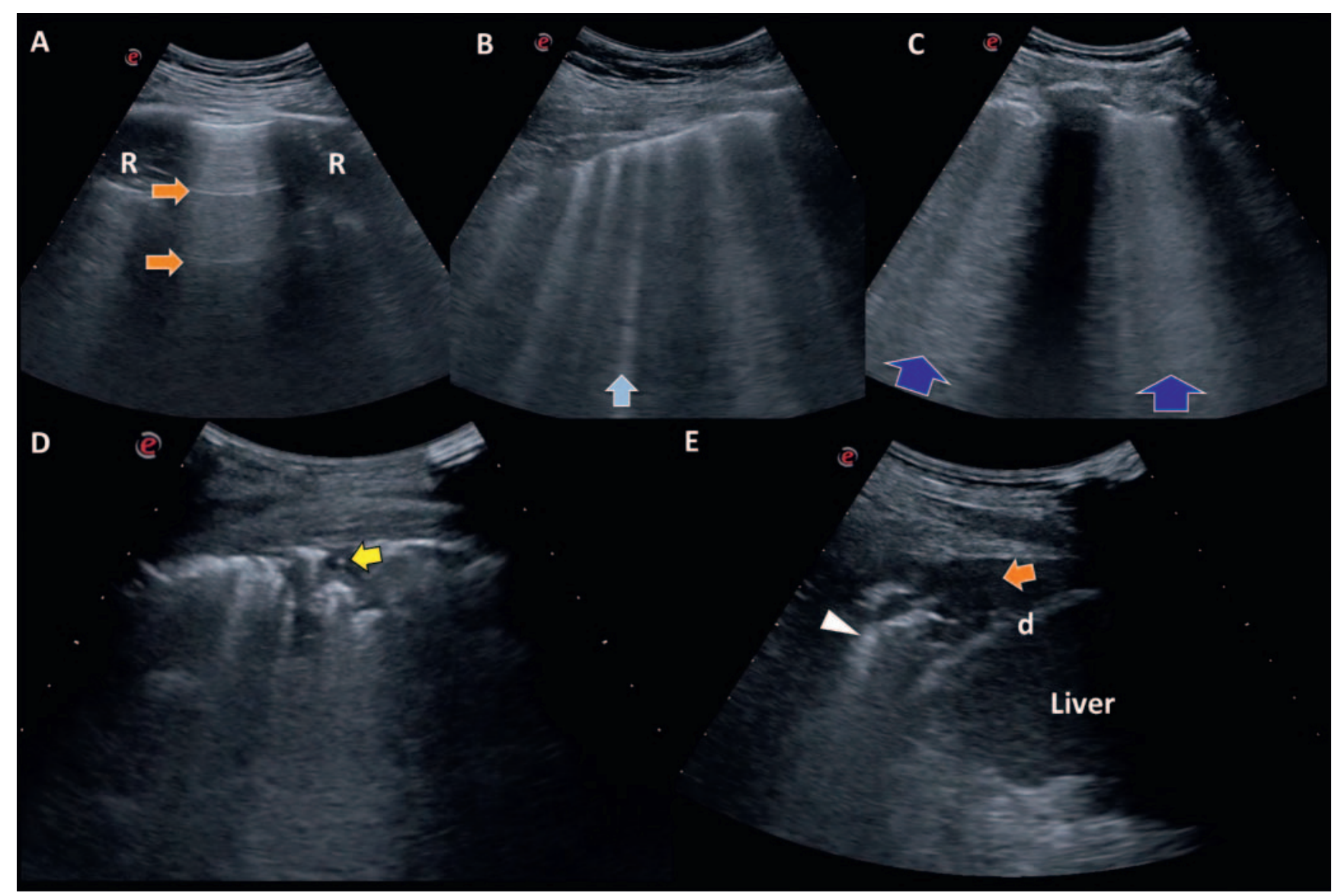

- Fig. 3 Illustrations of lung US patterns in COVID-19. A) normal A pattern in longitudinal scan (green arrows indicate A lines). R= rib shadowing; B) black and white or A/B pattern in a scan along the intercostal space (increased number of B lines, light blue arrow indicates one B line); C) coalescent B lines (indicated by the blu arrows) or «white lung» pattern; D) jagged/scarred pleural line with an emerging small consolidation (yellow arrow); E) more prominent basal consolidation of the right lung (orange arrow) with hyperechoic air bronchogram (white arrowhead). $d=$ diaphragm.

- Abb. 3 Darstellungen der Lungen-US-Muster bei COVID-19. A) normales A-Muster im Längsschnitt (grüne Pfeile zeigen A-Linien an). R= Rippenschatten; B) schwarz-weisses oder A/B-Muster in einer Aufnahme entlang des Interkostalraums (erhöhte Anzahl an B-Linien, hellblauer Pfeil zeigt eine B-Linie an); C) koaleszierende B-Linien (durch die blauen Pfeile angezeigt) oder „weisse Lunge“-Muster; D) gezackte/vernarbte Pleuralinie mit einer sich abzeichnenden kleinen Konsolidierung (gelber Pfeil); E) prominentere basale Konsolidierung der rechten Lunge (orangefarbener Pfeil) mit hyperechogenem Aerobronchogramm (weiße Pfeilspitze). $d=$ Zwerchfell.

spontaneously or favored by pulmonary regions of hyper-insufflation in ventilated patients. Whether US could also be utilized at the bedside to screen for patients who could be candidates that would perhaps benefit from non-invasive ventilation or from lying in prone position, also deserves investigation (e. g. extensive consolidations of the posterior regions, especially without bronchograms would not suggest any benefit in placing patients in a prone position; conversely consolidations with extensive air bronchograms are pulmonary regions likely to be recruited by increasing ventilation pressure). Basal lung US was not able to predict oxygenation response to the prone position in non COVID-19 acute respiratory distress syndrome, but was instead predictive of improved aeration gain in the anterior areas [11].

4) Ultrasound is very useful to guide pleural punctures for safer fluid drainage and for the assessment of the changes in the amount of pleural fluid, which is an established practice, although pleural effusions are not a typical feature of COVID-19.
5) There is clear scope for the US assessment of the heart and vena cava, particularly when COVID-19 might be combined with cardiovascular comorbidities. Ultrasound may guide the amount of intravenoius fluids to be infused (obviously less recommended in wet lungs and in overdistended vena cava) and assess left and right ventricular function in case of suspicion of cardiac failure. Such assessments may also be performed adequately with pocket size scanners [12].

6) Portable US scanners can also be transported easily to the home of patients with fever and mild symptoms or to mobile triage checkpoints for such patients to search for signs of pulmonary involvement. In this way, US could provide additional information beside pulmonary auscultation and oxygen saturation (with a finger pulse-oximeter), which are the only home or mobile checkpoint visit tools presently available for respiration investigation. However, the real cost or effectiveness of such a strategy is speculated. 
7) Ultrasound has the potential in the future to be operated remotely, with mechanical arms moving the transducer on the patient who lies isolated in protected rooms, limiting the risk of viral transmission.

8) A urgent need is felt of worldwide standardization of reporting modalities in lung US and especially in COVID-19 [13].

Despite the wide availability of US, its low cost, portability, patient acceptability, and ease of use in the poorly cooperative patients, in comparison to a CT or X-ray, there are a number of serious challenges in the use of US in the setting of COVID-19.

1) There is a prolonged exposure of US operators to patients and vice versa, longer and closer than with CT examinations, which can increase the risk of coronavirus transmission. Therefore, when scanning COVID-19 positive patients (or patients at high risk of being COVID-19 positive) US operators should wear adequate personal protective equipment (PPE), including FFP2 = N95 or FFP3 faces masks, gloves, disposable caps and shoe covers and protective glasses or goggles or face barriers ( $\mathbf{F i g} .4$ ). This equipment aims to protect operators from potentially infectious patients, but also to protect patients with unconfirmed suspicion upon COVID-19 from receiving COVID-19 from asymptomatic and unaware health care operators.

2) Ultrasound scanner boards are not designed to be cleaned with liquid disinfectants, liquids will almost invariably saturate the keyboard or the command buttons. New US scanners should take into consideration these aspects, namely the resistance to disinfectants and the ease to clean and disinfect the main body of the equipment.

3) Modalities of disinfection of transducers have been inadequately optimized and are unknown to many operators. Under normal conditions a cleaning tissue to wipe the transducers might be sufficient. However, with the increase in hazardous transmittable infections (e.g. SARS-CoV-2, carbapenemase-producing enterobacteriaceae, methicillin resistant staphylococcus, etc.) more research should be devoted to verify the most convenient and accessible method of disinfection that is useful in actual daily practice. Most manufacturers and scientific societies tend to suggest procedures such as immersion of the transducer in a disinfectant solution for 1-5 minutes or alternatively, in a stronger disinfectant solution for at least 30 seconds. However, such measures are felt to be complex, making adherence difficult $[14,15]$. Moreover, and importantly, immersion of transducers in potent disinfectant may damage some transducers after as few as 50-100 disinfecting cycles, making such procedures impracticable. Hence disinfecting procedures should be of minimal complexity, but also preserving patient and transducer safety.

4) The ability to maintain the US scanner protected from contamination within a COVID positive environment is not standardized. An US scanner may be entirely covered with transparent, thin and disposable nylon bags ( $\triangleright$ Fig. 4 ), but attention must be paid to avoid any potential overheating of the scanners. Reasonably, only the screen and the board could be covered. If no protective cover is used, it is difficult to be assured that every portion of the scanner is disinfected, should the scanner be moved outside a COVID-19 environment. Ideally each COVID-19 ward should have an US machine permanently in the ward area.

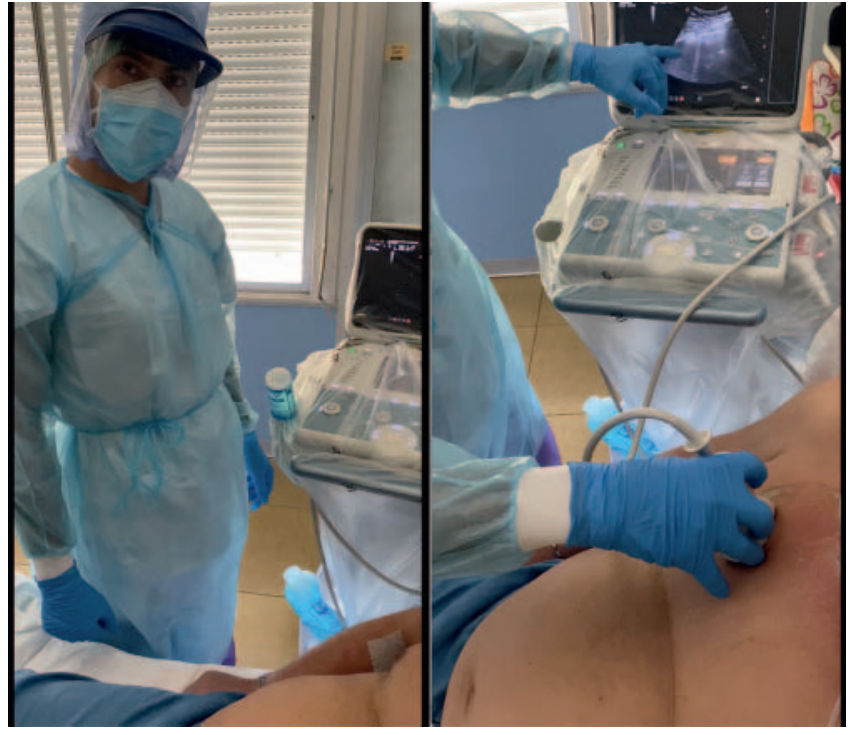

- Fig. 4 Ultrasound of COVID-19 infected patients demands extensive use of Personal Protective Equipment (PPE) and possibly protection of Ultrasound equipment in the hypothesis they should be moved out of the "dirty, COVID-19+ve" rooms, but can be carried out at the bedside, avoiding to move COVID-19+ve patients to hospital rooms utilized by COVID-19 negative subjects.

- Abb.4 Die Ultraschalluntersuchung von COVID-19-infizierten Patienten erfordert den umfangreichen Einsatz von persönlicher Schutzausrüstung (PSA) und möglichst den Schutz der Ultraschallgeräte. Dies in der Annahme, dass die Geräte aus den „schmutzigen, COVID-19 + ve“-Räumen wieder entfernt werden, die Untersuchung aber am Krankenbett durchgeführt werden kann, wodurch vermieden wird, dass COVID-19+ ve-Patienten in Krankenhauszimmer verlegt werden, die von COVID-19-negativen Patienten genutzt werden.

5) The interoperator reproducibility of lung US in the assessment of COVID-19 pulmonary involvement and of its severity has obviously not been tested for ethical reasons (in order not to expose two operators to the risk of becoming infected). Even though lung US is relatively easy to learn, in the hands of non-expert operators the reproducibility might be even lower.

Finally, and most importantly, every imaging procedure must be deemed essential for the ongoing clinical management of the patient, and for any US examination this is of paramount importance (not just lung US, but rather thyroid, carotid artery, liver, renal or any other examinations), as the US examination constitutes an infection risk. Ultrasound, like any other procedure performed on patients in isolation, can reduce the effectiveness of the isolation itself. Since COVID-19 individual infection is expected to last no longer than 2 to 6 weeks after symptomatic recovery, any US examination that can presumably be safely postponed by $6-8$ weeks must not be performed in patients with COVID-19 active infection. Similarly, the exposure of healthcare personnel should be limited to only the essential operations in order to prevent their contagion. 
Vorteile, offene Fragen und Herausforderungen des Einsatzes von Ultraschall in der Ära der COVID-19-Pandemie. Die Ansichten einer Gruppe von internationalen Experten aus aller Welt

In den allerletzten Tagen des Jahres 2019 wurde ein neuartiges Virus aus der Familie der Coronaviren namens SARS-CoV-2 identifiziert [1]. Es war Auslöser eines Ausbruchs von Pneumonien in Wuhan, China, einer Erkrankung, die als COVID-19 (COronaVirus Disease 2019) bezeichnet wurde. Das Virus zeigte eine rasche weltweite Ausbreitung, mit deutlich höheren Raten und wesentlich schwereren Krankheitsmanifestationen als das saisonale Influenzavirus. Vom Ausbruch in China ausgehend hat sich das Virus nach und nach auch auf Europa ausgebreitet, mit schweren Auswirkungen zunächst in Norditalien und später auch in anderen Europäischen Ländern und in den Vereinigten Staaten, die bis Ende März 2020 die größte Zahl dokumentierter Fälle aufwiesen. Da das Virus neuartig und hoch infektiös ist, sind alle Menschen potenziell empfänglich. Dazu kommt, dass der Ausbruch unerwartet und in einer dicht besiedelten chinesischen Großstadt auftrat und es somit zu einem sehr schnellen exponentiellen Anstieg der Fallzahlen kam. Dies führte in den medizinischen Einrichtungen zu einem enormen Zustrom von Patienten, die wegen anhaltend hohen Fiebers und Beeinträchtigung der Atemwege eine Untersuchung und Behandlung verlangten. Je nach Reaktion der lokalen Bevölkerung und der Behörden, wenn es um die Bekämpfung einer infektiösen diffusen Bedrohung der öffentlichen Gesundheit geht, kann es zu unterschiedlichen Auswirkungen dieser Epidemie kommen (https://www.youtube.com/watch? $\mathrm{v}=\mathrm{gxAaO} 2 \mathrm{rsdls}$ ) ( $\triangleright$ Abb. 1). Leider erfolgten - nicht nur in China, sondern auch in Norditalien, Spanien, Frankreich und Amerika, um nur einige der am stärksten betroffenen Länder zu nennen die Reaktionen der Behörden und die Einschränkungen der Bevölkerung nicht frühzeitig genug, um ein exponentielles Wachstum zu verhindern, was zu einem Explodieren der Fallzahlen führte. Dies hat unweigerlich dazu geführt, dass die Kapazität der Gesundheitssysteme überfordert war, insbesondere was die Krankenhausversorgung betrifft und die Fähigkeit, die Patienten den entsprechenden klinischen Abteilungen genau zuzuweisen. Dies hat insbesondere in Norditalien und Spanien, zu einem fast vollständigen Zusammenbruch der ansonsten flächendeckenden und hervorragenden Gesundheitssysteme geführt. Die übergroße Anzahl an Erkrankten hat die Kapazität der Krankenhäuser, die Gesundheitsversorgung wie gewohnt zu gewährleisten, überfordert und eine Art Kriegsszenario geschaffen.

Da keine spezifische Therapie für die Erkrankung existiert, gibt es mehrere Forderungen, mit denen man versucht, die Ausbreitung der Infektion zu begrenzen. So müssen Infizierte mit schnellen Labortests, idealerweise mit einer exakten klinischen Schnelldiagnose, früh genug erkannt werden, um positive Personen zu isolieren und eine weitere Ausbreitung der Infektion zu verhindern. Eine sachgerechte Triage der positiven Patienten in solche, die sicher zu Hause bleiben können und in solche, die ins Krankenhaus eingewiesen werden müssen, sollte erfolgen. Es wäre auch wichtig eine jegliche Verschlechterung früh vorherzusagen, um wenn möglich - die Intensität der Versorgung rechtzeitig zu erhöhen. Des Weiteren ist es nötig bei Atemversagen und Aufenthalt auf der Intensivstation einen optimalen Umgang mit dem Patienten zu gewährleisten. Die Übertragung dieser sich leicht verbreitenden Infektion muss während der Patientenversorgung ebenfalls vermieden werden.

Da es sich bei COVID-19 primär um eine Atemwegserkrankung handelt [2], würde man erwarten, dass die Lungenbildgebung für die Diagnose unerlässlich ist [3].

Es wurde berichtet, dass die Computertomographie (CT) eine hochsensitive Methode ist, um Befunde zu erheben, die auf eine COVID-19 bedingte pulmonale Beteiligung hindeuten, die bilaterale „subpleurale und im Unterlappen auftretende Milchglastrübungen“ einschließt [4]. Dennoch hat jegliche Trübung in der CT geringe Spezifität, da diese Erscheinungen auch durch andere Virusinfektionen verursacht werden [5]. Die gute Sensitivität und die guten positiven Vorhersagewerte sind daher nur im Rahmen einer COVID-19-Epidemie gültig, da bei Vorliegen von respiratorischen Symptomen „a priori“ eine sehr hohe Wahrscheinlichkeit für COVID-19 besteht. Doch selbst unter diesen Bedingungen ist die Fähigkeit der CT, bei Vorliegen negativer Lungenbefunde COVID-19 auszuschließen, bei weitem nicht ausreichend [6, 7].

Vor diesem Hintergrund hat ein internationales Expertengremium die Gelegenheit genutzt, die Rolle des Ultraschalls (US) beim Management von COVID-19 zu bewerten, um unseren Lesern einen Überblick über Vorteile aber auch über offene Fragen und Herausforderungen bei der Anwendung von US im Rahmen der COVID-19-Epidemie zu geben [8].

Typischerweise sind bei COVID-19 zunächst die Declivousareale der Lunge betroffen, die den oberflächlichen Lungenarealen entsprechen, meist in den posterioren basalen Arealen ( Abb. 2) [4], wahrscheinlich deshalb, weil kranke Patienten dazu neigen, die meiste Zeit im Bett zu sitzen oder zu liegen. Glücklicherweise kann man diese Areale mittels Thorax-US untersuchen und dort auftretende Anomalien können auch früh im Krankheitsverlauf erkannt werden, wie Su et al. in dieser Ausgabe des Journals zeigen [8]. Die pulmonale Beteiligung kann beträchtliche Ausmaße annehmen mit einer Progression nicht nur im Hinblick auf den lokalen Schweregrad, sondern auch auf die Ausbreitung, die alle Lungenareale bilateral einschließt. Im schwersten Stadium ist US fast ausnahmslos in der Lage, die Lungenbeteiligung zu erkennen, aber die Sensitivität des US in der Frühphase ist noch nicht endgültig geklärt ( $\triangleright$ Abb. 2).

Typische Muster der pulmonalen Beteiligung bei COVID-19 sind das Auftreten mehrerer B-Linien mit heterogener Beteiligung der Lunge (wobei sich A- und B-Muster in der Nähe mischen, anders als beim kardialen Lungenödem, das eine homogene Zunahme der B-Linien zeigt), das Auftreten verdickter und unregelmäßiger Pleuralinien, der Beginn kleiner oberflächlicher Konsolidierungen und in schwereren Fällen große Konsolidierungsareale mit Aerobronchogramm und auch minimale oder selten größere Pleuraergüsse ( $\triangleright$ Abb. $\mathbf{3})$. Da jedoch der Wert der CT bei COVID-19 immer noch in Frage gestellt wird [6], ist er in Bezug auf den US erwartungsgemäß noch wesentlich mehr umstritten und ungeklärt. 
Wir möchten daher eine Liste möglicher Vorteile des US vorschlagen und einige unbeantwortete klinische Fragen in diesem Bereich aufwerfen:

1) Ultraschall kann Anzeichen einer pulmonalen Beteiligung erkennen [8]. Befunde eines pulmonal interstitiellen Syndroms ( \pm mit Konsolidierungen) assoziiert mit Fieber, absoluter Lymphopenie und einem variablen Anstieg von LDH, Ferritin, C-reaktivem Protein und Interleukin-6 [9] sind in bei einer epidemiologischen Situation wie der Aktuellen höchst verdächtig für COVID-19. Ob zusätzliche Teste wie Rachen-/Nasenabstriche zur RNA-Testung [10] und/oder Röntgenaufnahmen des Thorax und/oder CT-Bildgebung dringend und sofort erforderlich sind oder ob die Patienten stattdessen direkt in COVID-19-Stationen verlegt werden können, muss eine Entscheidung bleiben, die auf den lokalen und sich ständig ändernden Umständen beruht. Dabei muss die Überfüllung der Erste-Hilfe-/Notfallstationen, die Zeit bis zur Diagnose bei RNA-Nachweis in Abstrichen [10] und bei der Thorax-CT-Bildgebung, die insbesondere bei hoher Nachfrage oft einige Stunden in Anspruch nimmt, berücksichtigt werden.

Um den angemessenen Einsatz von US bei der diagnostischen Triage von COVID-19 korrekt festzulegen, fehlt es an relevanten wissenschaftlichen Informationen. Wichtige Aspekte, die benötigt werden, sind unter anderem die Sensitivität der US-Technik bei verschiedenen Graden der pulmonalen Beteiligung (Su et al. berichten von einer begrenzten Zahl an Fällen) [8], der positive Vorhersagewert entweder im Rahmen einer endemischen Erkrankung mit COVID-19 oder unter normalen Bedingungen, der negative Vorhersagewert für eine leichte, mittlere und schwere Beteiligung. Kurz gesagt, trotz einiger Vorteile des US muss dessen Rolle in der klinischen Entscheidungsfindung bei Bildgebung eines individuellen Verdachtsfalls noch geklärt werden.

2) Ob US zur Erkennung der Progression (oder Regression) des Schweregrades der Lungenbeteiligung im zeitlichen Verlauf sowohl bei stationären als auch bei ambulanten Patienten eingesetzt werden kann und kosteneffektiv ist (mit anderen Worten: die Fähigkeit, zwischen leichter, mittelschwerer und schwerer Beteiligung zu unterscheiden), muss noch eingehend untersucht und geklärt werden. Bei positiver Antwort auf diese Frage würde es zu einer möglichen US-Anwendung beim Patienten-Monitoring kommen, möglicherweise in Verbindung mit Thorax-Röntgen oder CT.

3) Einsatz von US ist möglicherweise von Nutzen auf Intensivstationen, um die Auswirkung klinischer Eingriffe zu beurteilen, wie z. B. der Bronchoskopie, die auf die Wiederherstellung der bronchialen Durchgängigkeit abzielt, nachdem im US schlecht belüftete große Konsolidierungen festgestellt wurden. Mit Ultraschall kann zusätzlich ein Pneumothorax diagnostiziert werden, der entweder spontan oder begünstigt durch pulmonale Areale mit Hyperinsufflation bei beatmeten Patienten auftritt. Ebenso sollte untersucht werden, ob US auch am Krankenbett eingesetzt werden könnte, um Patienten zu screenen und zu identifizieren, die möglicherweise von einer nicht-invasiven Beatmung oder vom Liegen in Bauchlage profitieren würden (z. B. würden ausgedehnte Konsolidierungen der posterioren Areale, insbesondere ohne Bronchogramme, darauf hinweisen, dass die Patienten keinen Vorteil durch die Bauchlage hätten; umgekehrt sind Konsolidierungen mit ausgedehntem Aerobronchogramm
Lungenareale, die sich wahrscheinlich durch Erhöhung des Beatmungsdrucks erholen werden). Der basale Lungen-US war nicht in der Lage, die Oxygenierungsreaktion auf die Bauchlage bei akutem Atemnotsyndrom ohne COVID-19 vorherzusagen, sondern war stattdessen prädiktiv für einen verbesserten Belüftungserfolg in den anterioren Arealen [11].

4) Obwohl Pleuraergüsse kein typisches Merkmal von COVID-19 sind, ist US sehr nützlich und eine etablierte Praxis zur Unterstützung von Pleurapunktionen für eine sicherere Flüssigkeitsdrainage und zur Beurteilung der Volumenänderungen der Pleuraflüssigkeit.

5) Ein sehr eindeutiger Einsatzbereich für US ist die Beurteilung von Herz und V. cava, insbesondere wenn COVID-19 in Kombination mit kardiovaskulären Komorbiditäten auftritt. Ultraschall kann das Volumen der intravenös zu infundierenden Flüssigkeiten steuern (was bei feuchten Lungen und einer überdehnten Hohlvene offensichtlich weniger empfehlenswert ist) und kann die Funktion des linken und rechten Ventrikels bei Verdacht auf Herzinsuffizienz beurteilen. Solche Bestimmungen können auch mit Scannern im Taschenformat adäquat durchgeführt werden [12].

6) Tragbare US-Geräte können auch leicht zu Patienten mit Fieber und leichten Symptomen nach Hause oder zu mobilen Triage-Kontrollpunkten gebracht werden, um auf Anzeichen einer Lungenbeteiligung zu untersuchen. Auf diese Weise könnte US zusätzliche Informationen neben der Lungenauskultation und der Sauerstoffsättigung (mit einem Finger-Pulsoximeter) liefern, die derzeit die einzigen Instrumente zur Untersuchung der Atmung sind, die zu Hause oder an mobilen Kontrollpunkten zur Verfügung stehen. Über die tatsächlichen Kosten oder die Wirksamkeit einer solchen Strategie wird jedoch spekuliert.

7) Ultraschall bietet die Möglichkeit, in Zukunft ferngesteuert betrieben zu werden, wobei mechanische Arme den Schallkopf auf dem Patienten bewegen, der in einem Zimmer der Isolierstation liegt, wodurch das Risiko einer Virusübertragung begrenzt wird.

Trotz der breiten Verfügbarkeit von US, seiner geringen Kosten, der Portabilität, Patientenakzeptanz und einfachen Anwendung bei wenig kooperativen Patienten im Vergleich zu einer CT oder Röntgenuntersuchung gibt es hinsichtlich der Anwendung von US bei COVID-19 eine Reihe ernsthafter Herausforderungen.

1) Es besteht eine langanhaltende Exposition der US-Untersucher zu den Patienten und umgekehrt. Dieser Kontakt ist länger und enger als bei CT-Untersuchungen, was das Risiko einer CoronavirusÜbertragung erhöhen kann. Daher sollten US-Untersucher bei der Untersuchung COVID-19-positiver Patienten (oder von Patienten mit COVID-19 Verdacht) eine angemessene persönliche Schutzausrüstung (PSA) tragen, einschließlich FFP2 = N95- oder FFP3-Gesichtsmasken, Handschuhe, Einwegkappen und Schuhabdeckungen sowie Schutzbrillen oder Gesichtsschutz ( $\bullet$ Abb. 4). Diese Ausrüstung soll die Untersucher vor potenziell infektiösen Patienten schützen, aber auch die Patienten schützen, COVID-19 durch medizinisches Personal mit asymptomatischer oder unerkannter Infektion zu bekommen.

2) Für die Bedienfelder der Geräte ist eine Reinigung mit flüssigen Desinfektionsmitteln nicht vorgesehen, da die Flüssigkeiten fast ausnahmslos die Tastatur oder die Befehlstasten durchträn- 
ken. Bei neuen US-Geräten sollte daher berücksichtigt werden, dass diese widerstandsfähig gegenüber Desinfektionsmitteln sind und die Hauptbestandteile der Apparatur einfach gereinigt und desinfiziert werden können.

3) Die Art und Weise wie Schallköpfe desinfiziert werden ist unzureichend optimiert und vielen Anwendern nicht bekannt. Unter normalen Bedingungen kann ein Reinigungstuch zum Abwischen der Schallköpfe ausreichend sein. Angesichts der Zunahme gefährlicher übertragbarer Infektionen (z. B. SARS-CoV-2, Carbapenemase-produzierende Enterobacteriaceae, Methicillinresistente Staphylokokken usw.) sollte jedoch mehr Forschung betrieben werden, um die geeignetste und in der täglichen Praxis am besten anwendbare Desinfektionsmethode zu verifizieren. Die meisten Hersteller und wissenschaftlichen Gesellschaften neigen dazu, Verfahren vorzuschlagen wie das Eintauchen des Schallkopfes in ein Desinfektionsmittel für 1-5 Minuten oder alternativ in eine stärkere Desinfektionslösung für mindestens 30 Sekunden. Solche Maßnahmen werden jedoch als zu aufwändig empfunden, was ihre Einhaltung erschwert [13, 14]. Darüber hinaus, und dies ist wichtig, kann das Eintauchen der Schallköpfe in ein starkes Desinfektionsmittel einige Schallköpfe bereits nach 50-100 Desinfektionszyklen beschädigen, was solche Verfahren unpraktikabel macht. Daher sollten Desinfektionsmethoden wenig aufwändig sein, aber auch die Sicherheit von Patient und Schallköpfen gewährleisten.

4) Es gibt keine Standardisierung dafür, wie das US-Gerät in einer COVID-positiven Umgebung vor Kontamination geschützt werden kann. Das US-Gerät kann vollständig mit durchsichtigen, dünnen Einweg-Nylonhüllen bedeckt werden ( $\triangleright$ Abb. 4), aber es muss darauf geachtet werden, eine mögliche Überhitzung des Scanners zu vermeiden. Sinnvollerweise könnten nur der Bildschirm und das Bedienfeld abgedeckt werden. Wenn keine Schutzhülle verwendet wird, ist es schwierig zu gewährleisten, dass jeder Teil des Scanners desinfiziert wird, wenn das Gerät wieder aus der COVID-19-Umgebung herausgebracht wird. Idealerweise sollte in jeder COVID-19-Station ein US-Gerät permanent zur Verfügung stehen.

5) Die Interoperator-Reproduzierbarkeit des Lungen-US bei der Beurteilung der Lungenbeteiligung bei COVID-19 und ihres Schweregrades wurde offensichtlich aus ethischen Gründen nicht untersucht (um nicht zwei Untersucher dem Risiko einer Infektion auszusetzen). Auch wenn Lungen-US relativ leicht zu erlernen ist, könnte die Reproduzierbarkeit bei Untersuchern ohne Fachkenntnisse sehr gering sein.

Schließlich und vor allen Dingen muss jede Bildgebung für das kontinuierliche klinische Management des Patienten als notwendig erachtet werden. Dies ist für jede US-Untersuchung (nicht nur für den US der Lunge, sondern auch der Schilddrüse, Halsschlagader, Leber, Nieren oder irgendeine andere Anwendung) von zentraler Bedeutung, da die Untersuchung ein Infektionsrisiko darstellt. Ultraschall kann wie jedes andere Verfahren, das bei isolierten Patienten angewandt wird, die Wirksamkeit der Isolationsmaßnahme selbst verringern. Da im Einzelfall die Infektion mit COVID-19 voraussichtlich nicht länger als 2 bis 6 Wochen nach Symptomfreiheit fortbesteht, dürfen bei Patienten mit aktiver COVID-19-Infektion keine US-Untersuchungen durchgeführt wer- den, die voraussichtlich gefahrlos um 6-8 Wochen verschoben werden können. Ebenso sollte zur Vermeidung der Ansteckung von medizinischem Personal die Exposition begrenzt werden, indem nur die wesentlichen Arbeiten durchgeführt werden.

\section{Conflict of Interest}

Fabio Piscaglia: Bayer, ESAOTE, La Force Guerbet, GE Healthcare, Bracco, Siemens Healthineers; Federico Stefanini: None; Vito Cantisani: Bracco, Samsung, Canon; Paul Sidhu: Bracco, Siemens Healtineers, Samsung, Hitachi, GE Healthcare, Philips, ITREAS; Richard Barr: Philips, Mindray, Siemens, Canon, Bracco, Hologic, Samsung; Annalisa Berzigotti: none; Maria Cristina Chammas: none; Jean-Michel Correas: Canon MS, Hitachi MS, Philips Ultrasound, Siemens Ultrasound, Supersonic Imagine; Christopher Frank Dietrich: Bracco, Hitachi, Pentax, Siemens Healthcare, Mindray, Supersonic, Jazz, Youkey; Steven Feintstein: Bracco, DIA-Imaging, GE Healthcare; Pintong Huang: Bracco, Philips, Mindray; Christan Jenssen: FALK Foundation, Hitachi, Canon, Bracco and GE; Yuko Kono: Bracco, Lantheus, GE, Canon; Masatoshi Kudo: Bayer, Eisai, GE Healthcare; Ping Liang: None; Andrej Lyshchik: GE Healthcare, Bracco Diagnostics, Siemens Healthineers, Canon Medical Systems, Elsevier; Christian Nolsoe: None; Xyaoyan Xie: None; Francesco Tovoli: Bayer

\section{References}

[1] Zhu N, Zhang D, Wang W et al. A Novel Coronavirus from Patients with Pneumonia in China, 2019. N Engl J Med 2020; 382: 727-733. doi:10.1056/NEJMoa2001017

[2] Wu F, Zhao S, Yu B et al. A new coronavirus associated with human respiratory disease in China. Nature 2020; 579: 265-269. doi:10.1038/ s41586-020-2008-3

[3] Kanne JP. Chest CT Findings in 2019 Novel Coronavirus (2019-nCoV) Infections from Wuhan, China: Key Points for the Radiologist. Radiology 2020; 295: 16-17. doi:10.1148/radiol.2020200241

[4] $\mathrm{Ng} \mathrm{M}$, Lee EYP, Yang J et al. Imaging profile of the COVID-19 infection: Radiologic findings and literature review. Radiology: Cardiothoracic Imaging 2020; 2: e200034. doi:10.1148/ryct.2020200034

[5] Li Y, Xia L. Coronavirus Disease 2019 (COVID-19): Role of Chest CT in Diagnosis and Management. Am J Roentgenol 2020: 1-7. doi:10.2214/ Am J Roentgenol.20.22954 [Epub ahead of print]

[6] Hope MD, Raptis CA, Shah A et al. A role for CT in COVID-19? What data really tell us so far. Lancet 2020; [in press] doi:10.1016/S01406736(20)30728-5

[7] Xie X, Zhong Z, Zhao W et al. Chest CT for typical 2019-nCoV pneumonia: relationship to negative RT-PCR testing. Radiology 2020. doi:101148/radiol.2020200343

[8] Su ZZ, Lu W, Zhang S et al. A Clinical Study of Noninvasive Assessment of Lung Lesions in Patients with Coronavirus Disease-19 (COVID-19) by Bedside Ultrasound. Ultraschall in der Medizin 2020. doi:10.1055/ a-1154-8795

[9] Chen G, Wu D, Guo W et al. Clinical and immunologic features in severe and moderate Coronavirus Disease 2019. J Clin Invest 2020; [in press] doi:10.1172/JCl137244

[10] Won J, Lee S, Park M et al. Development of a Laboratory-safe and Lowcost Detection Protocol for SARS-CoV-2 of the Coronavirus Disease 2019 (COVID-19). Exp Neurobiol 2020; [in press] doi:10.5607/en20009

[11] Haddam M, Zieleskiewicz L, Perbet S et al. Lung ultrasonography for assessment of oxygenation response to prone position ventilation in ARDS. Intensive Care Med 2016; 42: 1546-1556. doi:10.1007/s00134-0164411-7 
[12] Nielsen MB, Cantisani V, Sidhu PS et al. The Use of Handheld Ultrasound Devices - An EFSUMB Position Paper. Ultraschall in Med 2019; 40: 3039. doi:10.1055/a-0783-2303

[13] Soldati G, Smargiassi A, Inchingolo R et al. Proposal for international standardization of the use of lung ultrasound for COVID-19 patients; a simple, quantitative, reproducible method. J Ultrasound Med 2020. doi:10.1002/jum.15285 [Epub ahead of print] PMID: 32227492
[14] Guidelines for cleaning and preparing external- and internal-use ultrasound probes between patients, safe handling, and use of ultrasound coupling gel. American Institute of Ultrasound in Medicine website. https://www.aium.org/accreditation/Guidelines_Cleaning_Preparing. pdf. Published 2018. Accessed 2020 April 3

[15] Ai A, Anderson L, Safdar $\mathrm{N}$ et al. Barriers and facilitators to standardization of ultrasound use and probe disinfection in the ambulatory setting. Infect Control Hosp Epidemiol 2020: 1-3. doi:10.1017/ice.2020.13 [Epub ahead of print] 